\title{
The Differences of the Personality Features and of the Emotional Empathy for Volunteering
}

\author{
Assoc. Prof. Helena Zaskodna
}

Ph.D., University of South Bohemia (USB) in Ceské Budejovice, Faculty for Health and Social Studies, Czech Republic

Assoc. Prof. Jiri Simek

M. D. University of South Bohemia (USB) in Ceské Budejovice, Faculty for Health and Social Studies, Czech Republic

Assoc. Prof. Zdeněk Mlcak

Ph.D., University of Ostrava, Faculty of Arts, Czech Republic

Doi:10.5901/ajis.2013.v2n8p411

\section{Abstract}

The article presents personality features of volunteers as relatively permanent psychological characteristics. It summarizes motives for volunteering discussed in the current concepts of volunteering and it introduces the Functional approach to volunteer motivation. Some results of the research supported by the Grant Agency of the Czech Republic No 407/11/0380, Prosocial behaviour and its personality aspects in the context of volunteering are presented. Research subjects were 240 volunteers, members of Czech Civic Associations of volunteers. Two questionnaires were used. Questionnaire NEO (authors P. T. Costa and R. R. McCraee) is based on the five-factor personality model (Big Five). They are: Neuroticism, Extraversion, Openness towards experience, Agreeableness and Conscientiousness. The emotional empathy of volunteers was assessed by Multi-dimensional Scale of Emotional Empathy for Adolescents and Adults - MEE (by D. R. Caruso and J. D. Mayer). In six subscales measuring the following factors: Suffering, Positive Sharing, Responsive Crying, Emotional Attention, Feel for Others, Emotional Contagion. Scores were compared with sample of the Czech population. Volunteers showed significantly higher score of the personality feature of Agreeableness, Extraversion and Conscientiousness. In the structure of emotional empathy of volunteers dominated Positive Sharing, Emotional Contagion and Feel for Others.

\section{Introduction}

The readiness to engage in prosocial activities in longer perspective finds its expression in volunteerism. Volunteerism is understood as unpaid service provided at no cost to a non-profit organization delivering directly or indirectly goods and services to individuals, groups of individuals or a thing (Wilson, 2000).

Volunteerism in the Czech Republic is regulated by legislation and defines volunteer activity as follows:

- help to unemployed, socially weak persons, handicapped persons, seniors, members of national minorities, immigrants, persons after sentence of confinement, drug addicted persons, persons suffering from domestic violence, as well as help with care for children, youth and families in their leisure time,

- help at natural, ecological or humanitarian disasters, at protection and improvement of environment, at care for preservation of cultural heritage, at organizing cultural or fund-raising charity actions for persons stated under letter a), or

- help at implementing development programs and within operations, projects and programs of international organizations and institutions, including international non-governmental organizations (by Act No 198/2002 Coll., on volunteer service).

Volunteer activity is mostly organized by volunteer centres and non-governmental non-profit organizations, so that the help recipient can completely rely on it in the agreed scope, time and place. The best known non-profit organizations in the Czech Republic are the Výbor dobré vưle - Nadace Olgy Havlové (Committee of Good Will - Olga Havlová Foundation), Český Červený křriž (Czech Red Cross), Fond ohrožených dětí (Fund of endangered children), Nadace člověk v tísni (Foundation human in strait). Further, they include civic associations including societies and clubs, purpose 
facilities of churches, e.g. Charity of the Czech Republic, and quasi-public societies.

\section{Characteristics of volunteers}

Volunteerism constitutes the basic building element of civic society, it helps preserving and strengthening such human values as sociability, interest in others and service to others. One of civic virtues, charity, as help to socially weak individuals is considered a significant part. Volunteerism is implemented in two forms:

a. Voluntary civic assistance, oriented predominantly on broader family and neighbours, in form of reciprocal services, but also help to other persons in a community (daily centre for seniors etc.).

b. Mutually beneficial volunteerism - takes place within the community, e.g. in a sports club or amateur gardener association established in the community.

The borders between the two above mentioned types of volunteerism are not accurate, voluntary help often penetrates both forms. It is based on the readiness of the volunteer offering his time and energy for the benefit of others, without expecting secondary advantages or profit.

The broadly adopted opinion on volunteers accepts the importance of the role of both demographic and personality factors and of social structure, e.g. family and culture. The demographic factors influence rather the human's attitude, his or her devotion to ideals and richness of his or her social networks leading directly to volunteerism. L. A. Penner and M. A. Finkelstein (1998) and others try to find explanation of the circumstances initiating the start of volunteer activities and staying in them in spite of considerable costs and effort that must be invested during a longer period. They seek substantiation in personality and demographic characteristics, in interpersonal relationships and situational factors and suggests that there are also non-social stimuli that can activate the wish to act as a volunteer. They can include personal circumstances in the individual's life (e.g. loss of a beloved person due to a disease) but also a specific feeling or idea that gets importance for the potential volunteer. For a lot of individuals, volunteer activity has its importance particularly in the fact that they can self-fulfil in it, strengthening their own self-confidence. For example persons unemployed in the long term can feel useful to others in volunteerism.

The motives of individual volunteers are not necessarily unambiguously positive and they do not necessarily prefer the benefit of others. The negative ones include e.g.: rise of feeling of own importance, deficit of self-respect together with the wish to meet even more miserable people, domineeringness, effort to dominate and control others. Helping behaviour can also serve to steady the disturbed mental balance in consequence of an unsolved or unsolvable personal problem. In this connection the "helper's syndrome" (Matoušek et al., 2003) must be mentioned - its background consists in a specific narcissistic disorder. The volunteer solves, mostly unknowingly, his or her early traumas of refused child, unsatisfied desire for recognition, gratefulness and admiration through helping. In all these cases, helping covers the actual motivation.

Certain set of personality dispositions including empathy play significant role in the decision to become a volunteer. For example M. Davis et al. (1999) found connection between disposition empathy and the readiness to engage in certain types of volunteer activities. Similarly L.A. Penner and coworkers (Penner, 2002; Penner, Dovidio, Schroeder, Piliavin, 2005) proved increased level of features of "prosocial personality", i.e. empathy, altruism and moral justification in volunteers.

\section{Emotional empathy}

The conceptualization of empathy in contemporary psychology does not present satisfactory results in terms of presenting a unified definition, however reference to the concept in terms of a psychological attribute, or a psychological condition can be traced in a number of studies. The majority of empathy aimed research projects accentuate either the notion's cognitive or emotional aspects, or their mutual integration. (Kunyk, Olson, 2001; Mlčák, 2004; Wiesman, 1996)

According to the theory of A. Mehrabin and N. Epstein (1972), emotional empathy represents the ability of an individual to experience through observation emotions felt by others. Within this situational framework, C. D. Batson (1987) presented his central empathy-altruism hypothesis, which asserts that empathy is the decisive motive of an altruistic behaviour, as it produces interest in the well-being of others. Empirical evidence further suggests that altruism and empathy relate in a positive correlation. (Mlčák, Záškodná, 2009) According to this theory, the presence of another individual in a state of distress can produce a broad range of emotional experiences in the observer, ranging from sadness and stress, which may in turn result in an egoistic attempt to escape the situation in order to avoid the displeasure. On the other hand, an individual that experiences an empathic interest will not seek to avoid the 
circumstances, but rather allow the stress to motivate him/her toward acting altruistically. Thus whereas distress can result in selfish motivations to help, empathic interest would generate an altruistic motivation with a ultimate goal of helping to benefit others, while the ratio of the two motives would determine the final behavioural response.

\section{Research Objectives, Methods, Sample}

The goal of research consisted in ascertaining the level of selected personality characteristics in volunteers. Goal consist identification of the level and structure of Big Five personality features, components of emotional empathy in volunteers.

\subsection{Methods}

The data collection was performed in two questionnaire methods based on the technique of introspective statements.

The first questionnaire, NEO (by authors P. T. Costa and R. R. McCraee is based on the five-factor personality model, Big Five. That model of personality in current psychology represents a significant integration theoretical and research platform used in different psychological subdisciplines. It measures personality features as relatively permanent characteristics shown in the way of thinking, experiencing and performing activities by which people mutually differ. They are: neuroticism, extraversion, openness towards experience, agreeableness and conscientiousness. The questionnaire included 60 items in which the respondents performed self-evaluation on Likert's scale from 0 to 4 points.

Also the Multi-dimensional Scale of Emotional Empathy for Adolescents and Adults (MEE), by D. R. Caruso and J. D. Mayer (1998), consists of 30 items in six subscales measuring the following factors:

1. Suffering $-S$, in the sense of sadness, worry at seeing pain of others, both people and animals. 2. Positive Sharing - PS, pleasing experiencing of joy and other positive emotions of other people. 3. Responsive Crying - RC, tendency to emotional response to negative conditions of other people. 4. Emotional Attention - EA, level of focusing attention on emotional manifestations of others. 5. Feel for Others - FO, emotional harmony in the sense of letting impress oneself by emotions of others. 6. Emotional contagion - EC, sensitivity to emotions of others in the sense of emotional induction.

The respondents express their agreement, disagreement or neutral position to individual items through the fivepoint Likert's scale using the zone of numbers from 1 to 5 .

Additionally to the above stated six factors, the multidimensional scale measures total Emotional Empathy given by the sum of partial scores.

\subsection{Research sample}

The study was implemented on a set of 240 respondents, members of Czech Civic Associations of volunteers, from Charity, ADRA. With regard to gender, the set included 194 women and 46 men in an age range from 20 to 43 years. Average age corresponded to 24,6 years. The volunteers were informed by a unified general instruction about the purpose of the study and the way of work with the questionnaires; the questioning was anonymous. The comparative set consisted of university students of helping professions of the following disciplines: psychology, social work, education, school teaching, general medicine (240 respondents, 194 women and 46 men, average age corresponded to 22,3 years).

\section{Results}

\subsection{Personality features of volunteers according to Five - factor model}

As expected, the factor of volunteerism constitutes distinctive source of variability for Big Five features. More exactly: 1. volunteers are more extraverted (differences in relation to comparative set); 2. more agreeable, and also 3. conscientious. Differences can be seen also in combined effect and interaction of both factors (gender - volunteerism). Female volunteers are more extraverted and more agreeable than male volunteers. (The differences are significant at $1 \%$ and $5 \%$ level of significance).

Table 1: Difference in Big Five features between volunteers and comparative set and interaction of volunteerism and 
gender factors

\begin{tabular}{|c|c|c|}
\hline Source of variability & Dependent variable & $\mathbf{F}$ \\
\hline \multirow{4}{*}{ Volunteerism } & Neuroticism &, $219 \mathrm{n}$ \\
\cline { 2 - 3 } & Extraversion & $\mathbf{6 , 1 5 ^ { * }}$ \\
\cline { 2 - 3 } & Openness &, $082 \mathrm{n}$ \\
\cline { 2 - 3 } & Agreeableness & $\mathbf{4 , 0 3 ^ { * }}$ \\
\cline { 2 - 3 } & Conscientiousness & $\mathbf{8 , 2 4 ^ { * }}$ \\
\hline \multirow{4}{*}{$\begin{array}{c}\text { Gender } \mathbf{x} \\
\text { volunteerism }\end{array}$} & Neuroticism & $1,05 \mathrm{n}$ \\
\cline { 2 - 3 } & Extraversion & $3,98^{*}$ \\
\cline { 2 - 3 } & Openness &, $516 \mathrm{n}$ \\
\cline { 2 - 3 } & Agreeableness & $\mathbf{4 , 2 1 ^ { * }}$ \\
\cline { 2 - 3 } & Conscientiousness &, $117 \mathrm{n}$ \\
\hline
\end{tabular}

$\mathrm{F}=$ calculation of resulting proportion of dispersions; $\left(^{* *}\right)$ significance at $1 \%$ level; $\left({ }^{*}\right)=$ significance at $5 \%$ level; $n=$ insignificant result.

In compliance with the results of studies implemented in volunteers (e.g. Penner \& Finkelstein, 1998; Bekkers., 2005; Záškodná, Mlčák, 2008), we expected higher level of Extraversion from volunteers of our study. The motive consists in the fact that extraverted, more affiliative individuals incline more to social situations and focus more frequently to other people. Their sociability and activity leads them to different social events and membership in groups. Statistic calculation specified the interpretation of the data acquired by us in the sense of significantly more marked feature of Extraversion in female volunteers, but not in male volunteers whose level of Extraversion corresponds to the population average. General conclusions on Extraversion of volunteers are not essentially changed by that because overwhelming majority of them consists of women. Men are represented only by a quarter of the total number of volunteers in the set researched by us. But the differences of man must be of course taken into consideration. Extraverted individuals probably seek warm and positive social interactions and such efforts of them can facilitate volunteer behaviour.

Extraversion can provide affiliative disposition needed for volunteerism. But the way to volunteerism does not lead only through personality features; the decision to become volunteer is co-determined by whether there is a link between the personality features related to volunteerism and prosocial motives. In other words, extraverted individuals may be more ready to volunteer work than introverts, but only when they are highly motivated by prosocial values. Extraversion by itself may not predispose the individual to volunteer behaviour, unless such individual does not appreciate helping others. The study has confirmed other personality features described in volunteers (Bierhoff, 2002)) like Agreeableness in both genders, particularly in female volunteers.

Agreeableness together with Conscientiousness co-creates the personality base of selfless helping. Agreeableness constitutes a dimension that includes a lot of socially positively appreciated personality aspects like altruism and sympathy. Marked positive qualities of students-volunteers proving successful in interpersonal context include warmth, communicativeness, cooperativeness, adaptability, readiness to help and kindness. From moral perspective, honest and unselfish humanists, sincere individuals full of emphatic understanding and respect to feelings of others prevail among volunteers. The third striking feature found in volunteers - Conscientiousness - includes a number of detailed descriptions concerning the approach to work and achieving of performance and results.

Individuals scoring high in Conscientiousness work independently, efficiently and in a disciplined way. They approach tasks systematically, solve problems logically, give clear answers to questions. They work reliably and try to meet their duties, are responsible in their approach to other people.

From the perspective of such characteristics, the personality profile of volunteers resembles the description of "productive orientation" by E. Fromm, embedded in the framework of assimilation and socialization, i.e. adaptation to the world of things and people. The productive orientation is characterized by the ability to give love (in the sense of care, responsibility, respect) and to work with effort for authentic life, when the person's activities are aimed at the good and can be seen particularly in contacts with other people and in relations of affection.

\subsection{Emotional empathy}

The distribution of the scores shows considerable variability of levels of individual components within the empathy structure and, as expected, also evident difference between genders. The highest score was recorded in the Positive Sharing subscale, in the sense of co-experience of positive emotions with others; further in the Suffering subscale, in the 
sense of sorrow, grief at seeing pain of others, people and animals, and finally in the Emotional Attention subscale, in the sense of attention paid to experience of others. The lowest levels were detected in the Reactive Crying subscale (particularly in men), as well as in Feel for Others.

Table 2: Subscales, average scores, standard deviations, statistical significance of emotional empathy in MEE

\begin{tabular}{|l|c|c|c|c|c|}
\hline & \multicolumn{4}{|c|}{ Volunteers } & $\begin{array}{c}\text { Volunteers } \mathbf{x} \\
\text { Comparative set }\end{array}$ \\
\hline Component & SD & $\begin{array}{c}\text { Men } \\
\text { Score } \\
\mathrm{n}=46\end{array}$ & $\begin{array}{c}\text { Women } \\
\text { Score } \\
\mathrm{n}=194\end{array}$ & $\begin{array}{c}\mathrm{F} \\
\text { Men } \mathbf{x} \text { Women } \\
\text { Sign. }\end{array}$ & $\begin{array}{c}\mathbf{F} \\
\text { Sign. }\end{array}$ \\
\hline Suffering & 4,6 & 3,1 & 3,5 & $3,82^{*}$ & $1,16 \mathrm{n}$ \\
\hline Positive Sharing & 4,1 & 3,8 & 3,8 & $0,12 \mathrm{n}$ & $\mathbf{5 , 1 9 ^ { * }}$ \\
\hline Responsive Crying & 3,2 & 1,5 & 2,9 & $\mathbf{8 , 4 9 ^ { * * }}$ & $0,25 \mathrm{n}$ \\
\hline Emotional Attention & 2,5 & 2,8 & 3,4 & $\mathbf{6 , 3 4 ^ { * * }}$ & $2,63 \mathrm{n}$ \\
\hline Feel for Others & 3,1 & 2,5 & 3,1 & $\mathbf{5 , 7 9 ^ { * * }}$ & $\mathbf{4 , 2 8 ^ { * }}$ \\
\hline Emotional Contagion & 2,5 & 3,1 & 3,2 & $0,17 \mathrm{n}$ & $\mathbf{4 , 7 4 ^ { * }}$ \\
\hline Empathy & 6,2 & 2,81 & 3,32 & $\mathbf{5 , 4 6 ^ { * * }}$ & $3,98^{*}$ \\
\hline
\end{tabular}

$\mathrm{F}=$ calculation of resulting proportion of dispersions; $\left.{ }^{* \star}\right)$ significance at $1 \%$ level; $\left({ }^{*}\right)=$ significance at $5 \%$ level; $n=$ insignificant result. Empathy $=$ the total score.

The results of research show some main findings.

1. The first of them consists in the markedly higher level of empathy in women as compared to men. Lower level of empathy in men constitutes a phenomenon verified by research and described in literature. For example the author of the multidimensional construct of empathy, including of the method (IRI) for its measurement, M. Davis (1983), states statistically significant difference of level of empathy between men and women, in the sense of higher empathy of women in its partial components.

2. The key component of the structure of emotional empathy in volunteers consists in Positive Sharing in the sense of emotional experiencing of positive feelings of others, co-experiencing of happiness and joy. The respondents have achieved the highest score in this partial component of empathy; it is at the same time the only sphere of emotional empathy where both men and women score the same. Men are able to rejoice, joy and be happy about happiness of others similarly to women, but they are not able to sympathize with or share negative emotions, pain and suffering of people and animals so much as their female counterparts; they have weaker feel for others as compared to women. This special phenomenon of higher emotional empathy of men for positive rather than for negative emotions of others can be related with higher feature anxiety of women, which is contained in higher neuroticism of women in general as compared to men.

3. Volunteers differ from non-volunteers by higher level of three out of six empathy components. They are: positive emotional response to positive emotional manifestations of others emotional "contagion" and feel for others. This finding is compatible with the above described extraversion of volunteers, with their positive emotional "tuning" towards emotional experiences of others.

\section{Conclusion}

1. The personality structure of volunteers is dominated by the factors of Extraversion, Agreeableness and Conscientiousness. The highest level of socially positive, other-oriented features of Extraversion and Agreeableness can be seen in female volunteers, within the whole set.

Their interpersonal orientation is typically characterized by altruism. They feel understanding and comprehension towards others, express favour to them, behave kindly and affably to them. They have confidence in others and prefer cooperation to competition. Characteristics like e.g. cruelty, suspiciousness, rejection of cooperation, vindictiveness and heartlessness can be seen only rarely in them.

2. The volunteers dispose of above-average level of empathy. Increased level of empathy ranks undoubtedly among positive and expected results. The inquiry performed by Z. Mlčák et al. (2005) showed that, besides the result of interaction with the social service worker, also the way of interaction and also the related personality characteristics of the social worker perceived by the client, e.g. kindness, openness, conscientiousness and 
emotional stability are very important for the clients. The significance of volunteers as workers providing services, who do not build on manager procedures, fulfill the legacy of C. R. Rotgers in empathic, kind approach to the client, accentuating the central role of the client.

This study brings only a part of the results of an extensive research focused on volunteering. Prospectively, other personality characteristics will be compared in order to understand more deeply the empathy and other prosocial characteristics in volunteering.

\section{Acknowledgement}

The research project is supported by the Grant Agency of the Czech Republic (GA CR), contract No. P 407/11/0380

\section{References}

Batson, C. D. (1991). The altruism question: Toward a socialpsychological answer. Hilsdale, Lawrence Erbaum Associates.

Bekkers, R. (2005). Participation in Voluntary Associations: Relations with Resources, Personality, and Political Values. Political Psychology, 26, 439-54.

Bierhoff, H.W. (2002). Prosocial Behaviour. New York, Taylor \& Francis.

Caruso, D. R., \& Mayer, J. D. (1998). A Measure of Emotional Empathy for Adolescents and Adults. Unpublished Manuscript. Available from: $\quad$ https://www.google.cz/search?q=Multidimensional\%20Scale\%20of\%20Emotional\%20Empathy\%20for\%20Adolescents \%20and\%20Adults\%20\&ie=utf-8\&oe=utf-8\&aq=t\&rls=org.mozilla:cs:official\&client=firefox-a\&channel=np\&source=hp

Costa, P. T., \& McCrae, R. R. (2001). The NEO - PIINEO-FFI manual supplement Odessa. Psychological Assesment Resources. In M.Hřebíčková, T. Urbánek. NEO pětifaktorový osobnostní inventár. Praha, Testcentrum.

Davis, M. H. (1983). Measuring individual differences in Empathy: Evidence for multidimensional aproach. Journal of Personality and Social psychology, $44,115-126$.

Kunyk, D., \& Olson J. K. (2001). Clarification of Conceptualtization of Empathy. Journal of Advanced Nursing, 35, 3, 317- 325.

Matoušek, O. a kol. (2003). Metody a řizení sociální práce. Praha, Portál.

Mehrabian, A., \& Epstein, N. (1972). A Measure of Emotional Empathy. Journal of Persona lity, 40, 4, 525 - 543.

Mlčák, Z. (2004). Základní psychologické aspekty sociální práce: afiliace, empatie a prosoci ální chování. Acta Facultatis Philosophicae Universitatis Ostraviensis, FF OU, 212, 9, 5 - 27.

Mlčák, Z. (Ed.), (2005). Profesní kompetence sociálních pracovníku a jejich hodnocení klien ty. Ostravská univerzita v Ostravě, Filozofická fakulta.

Mlčák, Z., \& Záškodná, H. (2006). Altruistická motivace, emocionální empatie a afiliace u vysokoškolských studentek sociální práce. In Acta Facultatis Philosophicae Universitatis Ostraviensis, FF OU, 47-60.

Mlčák , Z., \& Záškodná, H. (2009). Altruistic motivation, empathy, and affiliation. An Analysis of Data Collected Amongst Undergraduate Social Work Students Contribution to Creation of Psychology Conceptual Curriculum. In P.Tarabek, P. Záškodný, (Eds.), Educational and Didactic Communication.

Penner, L. A., Dovidio, J. F., Schroeder, D. A., \& Piliavin, J. A. (2005). Altruism and prosocial behavior. Annual Review of Psychology, $56,365-392$.

Penner, L. A., \& Finkelstein, M. A. (1998). Dispositional and Structural Determinants of Volunteerism. Journal of Personality and Social Psychology, 74, 2, 525-537.

Wilson, J. (2000). Volunteering. Annual Review of Sociology, 26, 215-240.

Wiseman T. (1996). A Concept Analysis of Empathy. Journal of Advanced Nursing, 23, 1162 -1167.

Záškodná, H., \& Mlčák,Z. (2008). Osobnostní aspekty prosociálního chování a empatie. Praha, Triton. 